\title{
MANAJEMEN KOLABORASI DALAM PENGELOLAAN LINGKUNGAN UNTUK MEWUJUDKAN PABRIK SEMEN RAMAH LINGKUNGAN
}

\author{
Wildan Rayadi ${ }^{1}$ \\ ${ }^{1}$ Manajemen Lingkungan, Pascasarjana Universitas Negeri Jakarta, \\ Komplek Universitas Negeri Jakarta Gedung M. Hatta, Jl. Rawamangun Muka, Jakarta Timur, Indonesia 13220 \\ Email: wildan_buffon@yahoo.co.id
}

\begin{abstract}
The results of this study focus on policy issues, guidelines, implementation, and expectations for Implementation of managemen environmental in order to realize environmentally friendly factory. This paper seeks to analyze the environmental impact, both in terms of benefits, as well as from environmental managemen, waste management, and evaluation \& monitoring environmental report through policy analysis. Evaluation of the program used by the researchers is a Grindle evaluation model that includes the evaluation component policy and program formulation, Program Implementation, Resources alocation and Outcomes. Evaluation of Policy and program formulation related to the policy AMDAL and AMDAL as guidance for environment management. Evaluation program implementation related to environment management, waste management and environmental monitoring. Resources alocation evaluation is related to facilities and infrastructure and budgeting. Outcomes evaluation is related to society complain handling, economy and social impact, This analysis tries to approach a strategy to consider: environmental management that benefits all parties, both government and society. The results of the analysis show the need for collaborative management among stakeholders (government, lokal government and lokal communities) in sustainable management of the site.
\end{abstract}

Keywords: cement plant, environmental impact, AMDAL

\begin{abstract}
Abstrak
Hasil penelitian ini fokus pada masalah kebijakan, pedoman, implementasi, dan harapan untuk Implementasi manajemen lingkungan untuk mewujudkan pabrik yang ramah lingkungan. Makalah ini berupaya menganalisis dampak lingkungan, baik dari segi manfaat, maupun dari pengelolaan lingkungan, pengelolaan limbah, dan evaluasi \& pemantauan laporan lingkungan melalui analisis kebijakan. Evaluasi program yang digunakan oleh para peneliti adalah model evaluasi Grindle yang mencakup kebijakan komponen evaluasi dan perumusan program, Implementasi Program, Sumber Daya lokasi dan Hasil. Evaluasi perumusan Kebijakan dan program terkait dengan kebijakan AMDAL dan AMDAL sebagai pedoman untuk pengelolaan lingkungan. Pelaksanaan program evaluasi terkait dengan pengelolaan lingkungan, pengelolaan limbah, dan pemantauan lingkungan. Sumber daya evaluasi lokasi terkait dengan fasilitas dan infrastruktur dan penganggaran. Evaluasi hasil terkait dengan penanganan keluhan masyarakat, dampak ekonomi dan sosial, Analisis ini mencoba mendekati strategi untuk mempertimbangkan: pengelolaan lingkungan yang menguntungkan semua pihak, baik pemerintah maupun masyarakat. Hasil analisis menunjukkan perlunya manajemen kolaboratif di antara para pemangku kepentingan (pemerintah, pemerintah daerah, dan masyarakat lokal) dalam pengelolaan situs yang berkelanjutan.
\end{abstract}

Keywords: pabrik semen, dampak lingkungan, $A M D A L$ 
PENDAHULUAN

Pembangunan Industri semen di Kabupaten Sukabumi memiliki potensi memberikan dampak negatif berupa meningkatnya tekanan terhadap lingkungan. Hal ini terjadi karena pembangunan yang kurang memperhatikan daya dukung dan daya tampung lingkungan setempat, yang pada akhirnya meningkatkan pencemaran dan kerusakan lingkungan. Pencemaran dan kerusakan lingkungan hidup tersebut menjadi beban sosial, yang pada akhirnya masyarakat dan pemerintah yang harus menanggung biaya pemulihannya.. Apabila hal ini dibiarkan terus menerus akan berakibat pada masalah-masalah yang semakin kompleks dan sulit penanganannya.

Oleh karenanya pembangunan yang harus dilakukan adalah pembangunan yang berwawasan lingkungan yaitu pembangunan yang memadukan lingkungan hidup dengan sumber daya alam, untuk mencapai keberlanjutan pembangunan yang menjadi jaminan bagi kesejahteraan dan mutu hidup generasi masa kini dan generasi masa depan.

Salah satu upaya yang dilakukan untuk meminimasi dampak negatif yang timbul dari suatu kegiatan maka dilakukan penyusunan kajian kelayakan lingkungan berupa AMDAL (Analisis
Mengenai Dampak Lingkungan Hidup) atau UKL \& UPL (Upaya Pengelolaan Lingkungan Hidup dan Upaya Pemantauan Lingkungan Hidup). Kedua instrumen lingkungan ini disatu sisi merupakan kajian kelayakan lingkungan bagi kegiatan yang akan memulai usaha tetapi disisi lain juga merupakan syarat yang harus dipenuhi untuk mendapatkan izin memulai usaha. Sehingga melalui dokumen ini dapat diketahui dampak yang akan timbul dari suatu kegiatan kemudian bagaimana dampak-dampak tersebut dikelola baik dampak negatif maupun dampak positif.

Beberapa penelitian yang berkaitan dengan pengelolaan situ agar dapat berkelanjutan adalah sebagai berikut: berikut:

Penelitian yang dilakukan oleh Fityatur Rohmah, Agus Luthfi, Aisah Jumiati, (2015) tentang Dampak Sosial Ekonomi Pabrik Semen Puger di Kecamatan Puger Kabupaten Jember dari hasil penelitian menyebutkan perusahaan dianggap sebagai lembaga yang dapat memberikan banyak keuntungan bagi masyarakat, seperti memberikan kesempatan kerja dan meningkatkan pendapatan. Namun dibalik dampak positif tersebut, keberadaan pabrik semen puger ternyata juga menimbulkan berbagai persoalan sosial dan lingkungan seperti kebisingan, kepadatan lalu lintas, polusi udara serta gangguan kesehatan 
yang disebabkan dari polusi udara (Rohmah dkk, 2015).

Penelitian lainnya Dampak Negatif Industri PT. Semen Indonesia Terhadap Masyarakat Desa Temandang (Wiwin, Nur, Afifah: 2014) hasil penelitian menyebutkan Dampak industrialisasi PT. Semen Indonesia terhadap masyarakat Desa Temandang sangat beragam dalam aspek ekonomi, lingkungan, social maupun budaya. Diantaranya adalah kelangkaan Sumber Daya Alam, konsumerisme masyarakat, perubahan sosial masyarakat progress, dan regress, kerusakan lingkungan, marginalisasi pekerjaan, pemudaran modal sosial, dan masalah ganti rugi terhadap dampak negatif yang tidak sesuai. Dampak negatif dari kehadiran PT. Semen Indonesia dirasakan oleh masyarakat oleh masyarakat yang terkena dampak industrialisasi terutama adalah masyarakat petani yang menjadi semakin termarginal, karena tidak mampu beradaptasi dengan iklim industrialisasi.Ekonomi. Dampak negatif dalam hal ekonomi adalah terdapat masyarakat yang mengalami perubahan social secara progress, dan regress. Masyarakat yang mengalami progress hanya segelintir saja yaitu para elit desa. Pihak yang paling diuntungkan adalah mantan Kepala Desa yang menjadi kepanjangan tangan dari PT. Semen Indonesia dan golongan menengah dan atas karena pendapatannya meningkat. Sedangkan masyarakat yang mengalami perubahan social secara regress yaitu masyarakat petani yang terkena dampak industrialisasi. Masyarakat petani yang memiliki lahan sempit ketika kehadiran PT. Semen Indonesia banyak yang mengalami mobilitas sosial vertical turun dari masyarakat petani menjadi pengangguran. Lingkungan. Kelangkaan Sumber Daya Alam yang dirasakan oleh masyarakat Desa Temandang, kawasan karst yang dimiliki masyarakat Desa Temandang dieksploitasioleh perusahaan semen. Eksploitasi batu Karst yang dilakukan oleh PT. Semen mencapai 1400 ha. Masyarakat petani tidak mampu menikmati kekayaan sumber daya alam yang mereka miliki karena eksploitasi tersebut. Dampak negatif yang lain dalam aspek lingkungan adalah kerusakan lingkungan. Kerusakan lingkungan yag terjadi di Desa Temandang adalah masalah debu yang biasanya membuat masyarakat mengalami sesak nafas, banjir, rumah yang retak akibat pengeboran. Debu biasanya terjadi ketika perusahaan semen beroperasi dan ketika truk-truk dari PT. Semen Indonesia melewati Desa Temandang karena banyak truk-truk besar yang keluar masuk (Afifah, 2014).

Dalam penelitian lain Kebijakan Pengelolaan Lingkungan Di Kawasan Kendeng Utara Provinsi Jawa Tengah 
(Hartuti, Purnaweni, 2014) hasil penelitian menyebutkan Kebijakan pengelolaan kawasan karst Kendeng Utara di Kecamatan Sukolilo, Kabupaten Pati, Provinsi Jawa Tengah berujud beberapa kebijakan yang bertumpu pada ciri wilayah sebagai deretan pegunungan karst, yang merupakan bagian dari pegunungan yang membentang mulai dari Tuban di sebelah timur hingga Grobogan di sebelah barat. Kebijakan-kebijakan ini melindungi kawasan tersebut sebagai kawasan lindung, namun dengan memberikan keleluasaan kawasankawasan tertentu untuk penambangan, sehingga dikeluarkan beberapa kebijakan khusus untuk kawasan karst Sukolilo.Pengelolaan lingkungan di kawasan Kendeng Utara di Kecamatan Sukolilo, dapat dilihat menurut POAC, yaitu: (1) Planning atau Perencanaan, mencakup kegiatan perencanaan dalam rangka pengelolaan lingkungan secara terpadu terhadap wilayah karst Kendeng Utara. Dibutuhkan semen untuk pembangunan fisik gedung, jalan, dan lain sebagainya, sehingga kepentingan industri semen harus terpenuhi, namun masyarakat juga memerlukan lahan untuk hidup;

Organizing (Pengorganisasian): ada beberapa kepentingan yang bersinggungan dalam pengelolaan kawasan karst di Kendeng Utara. Pemerintah, swasta, dan masyarakat lokal yang didukung media massa. Masing-masing dengan kepentingan mereka, di satu wilayah yang sama, yaitu wilayah Kecamatan Sukolilo; dan Actuating (Pelaksanaan): terdapat dorongan pelaksanaan konservasi sumberdaya alam, dan meningkatnya peran stakeholders dan kelembagaan yang terlibat. Namun belum muncul pelaksanaan optimatisasi peman-faatan sumberdaya alam secara efisien (Purnaweni, 2014).

Yang menjadi pembeda dari hasil penelitian sebelumnya dan juga merupakan esensi dari penelitian ini yaitu terkait dengan indikator kesuksesan dari implementasi kebijakan diantaranya mengenai evaluasi kebijakan, perumusan tujuan dari kebijakan, penyusunan program program yang relevan, perencanaan desain kerja dan aktivitasaktivitas yang dilakukan

\section{METODOLOGI}

Metode penelitian merupakan suatu pendekatan terhadap penetapan mengenai tata cara penelitian yang dilakukan secara tersusun dan sistematis untuk mencapai tujuan penelitian yang di tetapkan. Penelitian ini menggunakan metode penelitian Policy Research. Dengan pendekatan metode deskriptif kualitatif dengan metode Evaluasi yang dikembangkan oleh Grindle (1980). Penggunaan metode ini diharapkan dapat memberikan gambaran yang lebih 
mendalam dan menyeluruh mengenai realitas dan proses sosial yang akan diteliti. Serta tidak mengisolasikan individu atau organisasi kedalam variabel atau hipotesis tetapi perlu memandangnya bagian dari suatu keseluruhan.

Instrumen dalam penelitian ini adalah observasi, wawancara, dan dokumentasi. Dalam penelitian ini dibutuhkan manusia sebagai peneliti karena manusia dapat menyesuaikan sesuai dengan keadaan lingkungan. Sebagai acuan dari evaluasi Pelaksanaan kebijakan Sebagai acuan dari evaluasi Pelaksanaan kebijakan adalah uu no 27 tahun 2012 tentang pengelolaan lingkungan.

\section{Tabel 1. Acuan Evaluasi Kebijakan}

\begin{tabular}{|c|c|c|c|}
\hline Komponen & Aspek & $\begin{array}{c}\text { No. Butir } \\
\text { Pernyataan }\end{array}$ & $\begin{array}{l}\text { Jumlah } \\
\text { Pernyataan }\end{array}$ \\
\hline \multirow{2}{*}{$\begin{array}{l}\text { Eormulasi } \\
\text { kebjakanan }\end{array}$} & 1) Kebjjakan AMDAL & 1 & 1 \\
\hline & $\begin{array}{l}\text { 2) AMDAL sebagai pedoman } \\
\text { pengelolaan lingkungan }\end{array}$ & 2,3 & 2 \\
\hline \multirow{3}{*}{$\begin{array}{c}\text { Pelaksanaan } \\
\text { program }\end{array}$} & 1) Pengelolaan lingkungan & $4,5,6,7,8,9$ & 6 \\
\hline & 2) Pengelolaan limbah pabrik & 10,11 & 2 \\
\hline & $\begin{array}{l}\text { 3) Pemantauan lingkungan dan } \\
\text { monitoring }\end{array}$ & $12,13,14,15,16,17,18$ & 7 \\
\hline \multirow{2}{*}{$\begin{array}{c}\text { Alokasi } \\
\text { sumber dava }\end{array}$} & 1) Sarana dan prasarana & $19,20,21$ & 3 \\
\hline & 2) Rembiayaan & $22,23,24,25,26$ & 5 \\
\hline \multirow{3}{*}{ Outcomes } & 1) Keluhan masyarakat sekitar & $27,28,29,30$ & 4 \\
\hline & 2) Dampak ekonomi & 31 & 1 \\
\hline & 3) Sosial & 32 & 1 \\
\hline
\end{tabular}

Evaluasi program yang digunakan oleh peneliti adalah metode evaluasi yang dikembangkan oleh grindle yang mencakup komponen evaluasi formulasi kebijakan, pelaksanaan program, alokasi sumber daya dan target outcomes. Formulasi kebijakan berkaitan dengan
UU No 27 tahun 2012 tentang ijin lingkungan.

Desain penelitian evaluasi kebijakan yang dikembangkan oleh peneliti sebagai berikut :

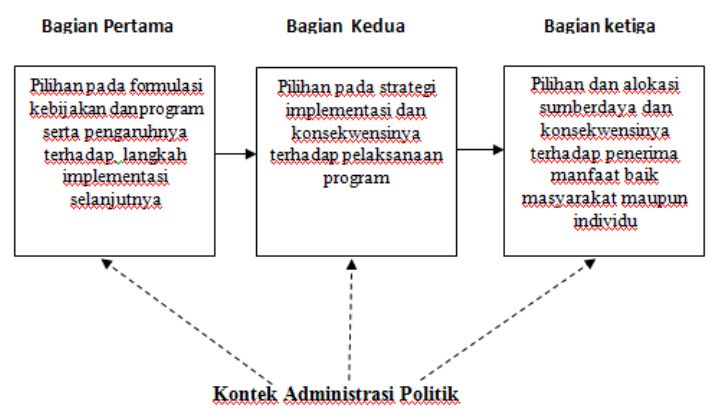

Gambar 1. Desain Evaluasi implementasi kebijakan pengelolaan lingkungan dengan metode Grindle (1980).

Tujuan dari penelitian ini adalah untuk mengevaluasi Implementasi kebijakan pengelolaan lingkungan di PT Semen Jawa dalam rangka mewujudkan pabrik semen ramah lingkungan dilihat dari kesesuaian dengan aspek formulasi kebijakan dan program, pelaksanaan program, alokasi sumber daya dan outcomes. process dan product. Data penelitian yang diperoleh selanjutnya dilakukan dianalisa secara deskriptif kualitatif. Pendeskripsian data penelitian ini dilakukan dengan menggunakan statistik deskriptif.

Teknik analisis data akan dilakukan seperti pada tabel berikut ini:

Tabel 3.2 Teknik Pengumpulan Data dan Analisis Data 


\begin{tabular}{|c|c|c|c|c|c|}
\hline Komponen & & $\begin{array}{l}\text { Aspek yang } \\
\text { Diexaluasi }\end{array}$ & Sumber. Data & $\begin{array}{c}\text { Teknik.Pengumpulan } \\
\text { Data }\end{array}$ & $\begin{array}{l}\text { Analisis } \\
\text { Data }\end{array}$ \\
\hline \multirow[b]{2}{*}{$\begin{array}{l}\text { Formulasi } \\
\text { kebhijakgn }\end{array}$} & & $\begin{array}{l}\text { Kebjiakan } \\
\text { AMDAL }\end{array}$ & \multirow[b]{2}{*}{ 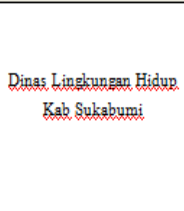 } & \multirow[b]{2}{*}{$\begin{array}{l}\text { Studi dekumen, } \\
\text { Waxancaras } \\
\text { ancket penelitian }\end{array}$} & \multirow[b]{2}{*}{ Deskriptif } \\
\hline & 2) & 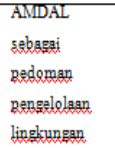 & & & \\
\hline \multirow{3}{*}{$\begin{array}{l}\text { Pelaksangan } \\
\text { program }\end{array}$} & & 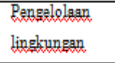 & \multirow{3}{*}{ 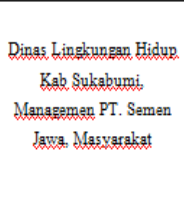 } & \multirow{3}{*}{$\begin{array}{l}\text { Wayancara, Angetet } \\
\text { Penelitim }\end{array}$} & \multirow[b]{3}{*}{ Deskriptif } \\
\hline & & 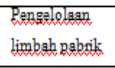 & & & \\
\hline & 3) & 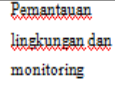 & & & \\
\hline \multirow[t]{2}{*}{$\begin{array}{l}\text { Alokasi sumber } \\
\text { days }\end{array}$} & 1) & $\begin{array}{l}\text { Sarana dan } \\
\text { Drasarang }\end{array}$ & \multirow[t]{2}{*}{ PT. Semen Igwa } & \multirow[t]{2}{*}{$\begin{array}{l}\text { Wawancara Anelet } \\
\text { Penelititin. }\end{array}$} & \multirow{2}{*}{ Deskkriptif } \\
\hline & 2) & Pembiaxan & & & \\
\hline \multirow[t]{3}{*}{ Outcomes } & 1) & $\begin{array}{l}\text { Keluhhon } \\
\text { masyaratat } \\
\text { sekitar }\end{array}$ & \multirow[t]{3}{*}{ 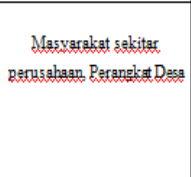 } & \multirow{3}{*}{$\begin{array}{l}\text { Waysancara, Anceket } \\
\text { Penelititin }\end{array}$} & \multirow{3}{*}{ Deskriptif } \\
\hline & 2). & $\begin{array}{l}\text { Dampal } \\
\text { eksongmi }\end{array}$ & & & \\
\hline & 3), & Sosial & & & \\
\hline
\end{tabular}

\section{HASIL DAN PEMBAHASAN}

Identitas pemrakarsa dan domisili usaha dan atau kegiatan :

Nama Perusahaan/Pemrakarsa :

\section{PT. SEMEN JAWA}

Alamat Perusahaan/Pemrakarsa :

Jl. Pelabuhan 2 Km 11 Kp. Talagasari RT 004/006 Desa Sirnaresmi Kecamatan Gunungguruh Kabupaten Sukabumi, Provinsi Jawa Barat

Bidang usaha dan atau kegiatan : Industri Semen

Lahan yang digunakan meliputi lahan untuk tapak pabrik, tapak jalan akses dan fasilitas pabrik lainnya. Batasbatas lahan yang digunakan dan tata letak usaha dan/atau kegiatan disajikan pada Gambar 4.1. Lahan yang akan digunakan untuk tapak penambangan bahan baku semen berbatasan dengan lahan permukiman, lahan kegiatan jasa dan perdagangan, lahan perkebunan, lahan persawahan, dan lahan penambangan batu gamping.

Lahan yang akan digunakan untuk tapak pabrik berbatasan dengan lahan permukiman, lahan perkebunan, lahan persawahan irigasi teknis, persawahan tadah hujan, dan lahan penambangan yang diusahakan rakyat. Lahan yang akan digunakan untuk tapak jalan akses berbatasan dengan lahan permukiman, lahan perkebunan, lahan persawahan.

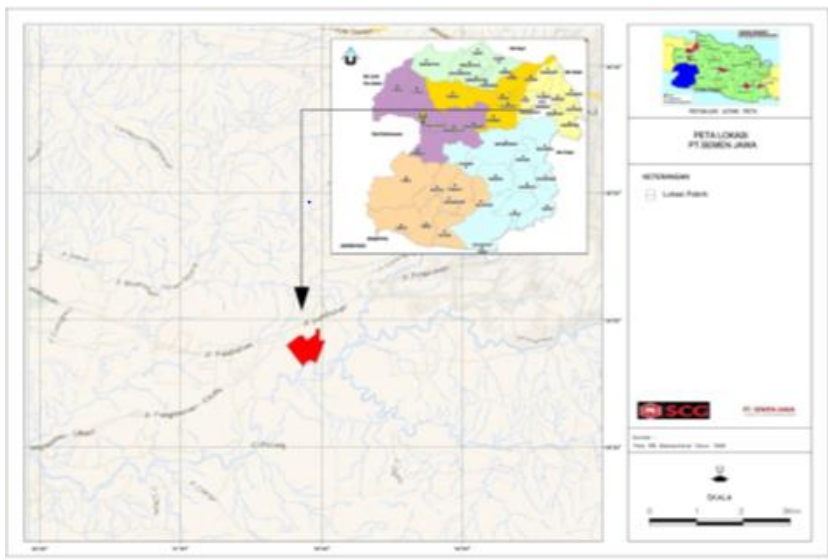

Gambar 4.1 Peta Lokasi PT. Semen Jawa

\section{Sumber: AMDAL PT. Semen Jawa}

Target responden sebagai target angket penelitian dan wawancara mendalam (in-depth Interview) berasal dari unsur manajemen perusahaan, karyawan perusahaan, Dinas Lingkungan hidup dan masyarakat sekitar PT.Semen Jawa sebagai berikut:

Tabel 4.1. Daftar Informan Wawancara (In-depth Interview) 


\begin{tabular}{|c|l|l|l|}
\hline No & $\begin{array}{c}\text { Nama } \\
\text { Informan }\end{array}$ & $\begin{array}{l}\text { Institusi/SK } \\
\text { PD }\end{array}$ & $\begin{array}{l}\text { Posisi/Jabat } \\
\text { an }\end{array}$ \\
\hline 1 & $\begin{array}{l}\text { Denis } \\
\text { Eriska }\end{array}$ & $\begin{array}{l}\text { Dinas } \\
\text { Lingkungan } \\
\text { Hidup kab } \\
\text { Sukabumi }\end{array}$ & $\begin{array}{l}\text { Pengawas } \\
\text { AMDAL }\end{array}$ \\
\hline 2 & $\begin{array}{l}\text { Tengku } \\
\text { KH ST }\end{array}$ & $\begin{array}{l}\text { PT Semen } \\
\text { Jawa }\end{array}$ & $\begin{array}{l}\text { Managemen } \\
\text { PT Semen } \\
\text { Jawa }\end{array}$ \\
\hline 3 & $\begin{array}{l}\text { TB Arief } \\
\text { Ramadha } \\
\text { ni, ST }\end{array}$ & $\begin{array}{l}\text { PT Semen } \\
\text { Jawa }\end{array}$ & $\begin{array}{l}\text { Wakil KTT } \\
\text { PT Semen } \\
\text { Jawa }\end{array}$ \\
\hline 4 & $\begin{array}{l}\text { Ari } \\
\text { Dijaya } \\
\text { Priyadi, } \\
\text { SKM }\end{array}$ & $\begin{array}{l}\text { PT Semen } \\
\text { Jawa }\end{array}$ & $\begin{array}{l}\text { HSE PT } \\
\text { Semen Jawa }\end{array}$ \\
\hline 5 & $\begin{array}{l}\text { Rizal } \\
\text { Indarsya } \\
\text { h }\end{array}$ & $\begin{array}{l}\text { Desa } \\
\text { Sirnaresmi }\end{array}$ & $\begin{array}{l}\text { Kepala } \\
\text { desa }\end{array}$ \\
\hline 6 & $\begin{array}{l}\text { Ade } \\
\text { Sultan } \\
\text { Tato ST }\end{array}$ & $\begin{array}{l}\text { Masyarakat } \\
\text { Desa } \\
\text { Sirnaresmi }\end{array}$ & $\begin{array}{l}\text { Tokoh } \\
\text { Masyarakat }\end{array}$ \\
Adapun \\
untuk \\
responden
\end{tabular}

\begin{tabular}{|c|l|c|}
\hline No & $\begin{array}{c}\text { Sumber } \\
\text { Informan/Responden }\end{array}$ & $\begin{array}{c}\text { Jumlah } \\
\text { Pengisian } \\
\text { Angket } \\
\text { Penelitian } \\
\text { (Orang) }\end{array}$ \\
\hline 3 & $\begin{array}{l}\text { Aparat Desa sirna } \\
\text { Resmi }\end{array}$ & 1 \\
\hline 4 & $\begin{array}{l}\text { Karyawan PT } \\
\text { Semen Jawa } \\
\text { Sukabumi }\end{array}$ & 5 \\
\hline 5 & Masyarakat & 10 \\
\hline \multicolumn{2}{|c|}{ TOTAL } & $\mathbf{2 0}$ \\
\hline
\end{tabular}

Adapun profil data responden untuk pengisian angket penelitian dapat digambarkan dalam grafik atau bagan sebagai berikut ini:

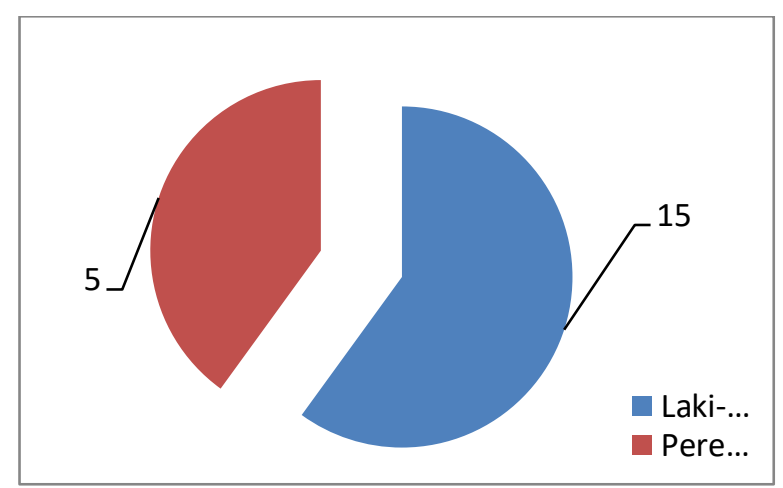

Grafik 4.1. Responden

perusahaan, Dinas Lingkungan hidup dan masyarakat sekitar yang berada disekitar lokasi PT Semen Jawa dengan dengan daftar responden sebagai berikut:

Tabel 4.2. Daftar Responden Pengisian Angket Penelitian

\begin{tabular}{|c|l|c|}
\hline No & \multicolumn{1}{|c|}{$\begin{array}{c}\text { Sumber } \\
\text { Informan/Responden }\end{array}$} & $\begin{array}{c}\text { Jumlah } \\
\text { Pengisian } \\
\text { Angket } \\
\text { Penelitian } \\
\text { (Orang) }\end{array}$ \\
\hline 1 & $\begin{array}{l}\text { Dinas Lingkungan } \\
\text { Hidup Kab } \\
\text { Sukabumi }\end{array}$ & 2 \\
\hline 2 & $\begin{array}{l}\text { Managemen PT. } \\
\text { Semen Jawa }\end{array}$ & 2 \\
\hline
\end{tabular}


RW dan Ketua RT dilingkungan RT 03 dan RW 05

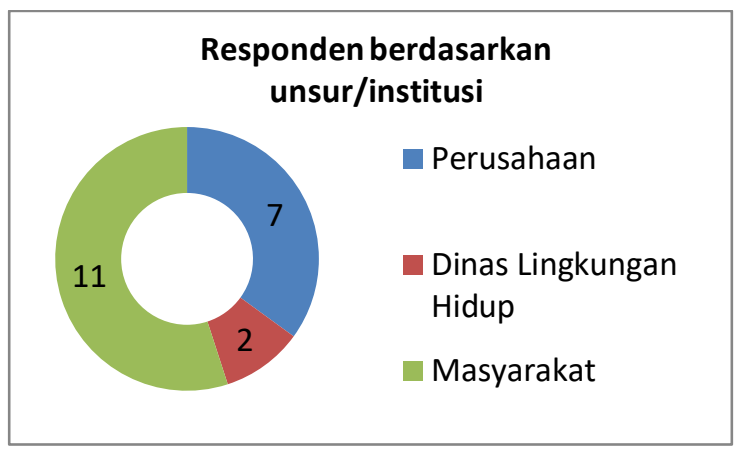

Grafik 4.2. Responden Berdasarkan Unsur/Institusi

Model evaluasi kebijakan Grindle (1980) menitikberatkan pada 3(Tiga) bagian pilihan kritis dalam proses pelaksanaan kebijakan, yaitu 1) Bagian pertama terkait pilihan pada formulasi kebijakan dalam program serta pengaruhnya terhadap langkah implementasi selanjutnya: 2)bagian kedua terkait pilihan pada strategi implementasi dan konsekuensinya terhadap pelaksanaan program; 3) bagian ketiga pada pilihan alokasi sumber daya dan konsekuensinya terhadap penerima manfaat baik masyarakat ataupun individu dalam masyarakat (Grindle, 1980).

Evaluasi Pelaksanaan Pengelolaan Lingkungan dalam rangka mewujudkan pabrik semen ramah lingkungan dengan menggunakan model Grindle dijelaskan sebagai berikut:

Kebijakan yang dievaluasi pada penelitian ini adalah uu no 27 tahun 2012
DOI : doi.org/10.21009/jgg.081.03

tentang ijin lingkungan yang mengatur pengelolaan lingkungan termasuk didalamnya implementasi dan pelaksanaan AMDAL.

Mengacu pada model evaluasi Grindle, formulasi kebijakan yang dimaksudkan pada penelitian ini menyangkut Implementasi Kebijakan Lingkungan Dalam Rangka Mewujudkan Pabrik Ramah Lingkungan. Bedasarkan hasil wawancara mendalam dengan beberapa informan kunci yang terkait diperoleh informasi bahwa kebijakan yang dibuat sudah cukup jelas mengatur terkait implementasi AMDAL di perusahaan. Pengelolaan lingkungan yang dimaksud dalam peraturan tersebut dilakukan melalui implementasi AMDAL.

Pengelolaan lingkungan yang dimaksud dalam peraturan tersebut dilakukan melalui implementasi AMDAL yang sebagaimana disampaikan oleh informan yang diwawancarai menyatakan kebijakan uu no 27 tahun 2012 telah cukup jelas mengatur dan mengamanatkan pengelolaan lingkungan melalui AMDAL.

Hasil angket penelitian berkaitan dengan formulasi kebijakan dan programmenunjukan bahwa:

(a) Peraturan pemerintah No 27 tahun 2012 tentang ijin lingkungan merupakan pedoman untuk upaya pengelolaan lingkungan di PT 
Semen Jawa dalam Rangka menjadikan industry ramah lingkungan

(b) Peraturan pemerintah no 27 tahun2012 tentang ijin lingkungan merupakan dasar bagi kebijakan pengelolaan lingkungan dalam rangka menjadikan pabrik semen ramah lingkungan;

1. pelaksanaan program

Selanjutnya konsep evaluasi kebijakan Grindle (1980), bagian kedua terkait fokus evaluasi pelaksanaan program. Dari beberapa program yang diatur dalam UU No 27 Tahun 2012 tentang Ijin Lingkungan bahwa kebijakan pengelolaan lingkungan dalam rangka menjadikan pabrik semen ramah lingkungan yaitu pengelolaan lingkungan, penglelolaan limbah, pemantauan lingkungan dan monitoring. Berdasarkan hasil wawancara mendalam dari 3 (Tiga) Program tersebut PT semen Jawa telah melaksanakan ke 3 (Tiga) Program melalui:

1) teknologi ramah lingkungan diantarnya yaitu Elektrostatik Precifikator Dan Bag Filter untuk mengurangi polusi debu

2) Melakukan pengolahan air secara tertutup, hal ini bermaksud untuk mengurangi debit yang digunakan dalam proses produksi. Karena pabrik ini tidak menggunakan air tanah tetapi menampung air dengan membuat pound penampung air.

3) Mengimplementasikan program $3 R$ (Reduce, Reuse, Recycle) untuk mengurangi limbah yang ditimbulkan dalam proses produksi

4) Pabrik PT semenjawa telah memasang CEMS (Continuous Emission Monitoring System) teknologi ini membantu untung memonitoring tingkat emisi yang ditimbulkan oleh mesin produksi Mengacu pada model evaluasi Grindle, formulasi kebijakan yang dimaksudkan pada penelitian ini menyangkut formulasi kebijakan yang dilakukan PT Semen Jawa melalui UU no 27 Tahun 2012 tentang Ijin Lingkungan untuk pelaksanaan pengelolaan lingkungan dalam rangka menjadikan pabrik semen ramah lingkungan sudah tepat dan diterima oleh seluruh Stakeholder baik aparat pemeritah (SKPD Terkait) maupun masyarakat selaku penerima manfaat.

Berdasarkan hasil interview dengan pihak PT Semen Jawa ( Bapak tengku kh selaku manager, Bapak Ari Dj selaku HSE dan Bapak TB Arief selaku wakil KTT) menyatakan PT Semen Jawa telah mengimplementasikan Kebijakan Lingkungan sebagaimana yang telah diatur dalam UU No 27 tahun 2012 yaitu pengelolaan lingkungan, penglelolaan limbah, pemantauan lingkungan dan 
monitoring. UU Nomor 27 tahun 2012 memang menjadi pedoman utama dan landasan dasar dalam implementasi kebijakan lingkungan PT Semen Jawa dalam rangka mewujudkan pabrik semen ramah lingkungan.

Selanjutnya konsep evaluasi kebijakan Grindle (1980), bagian kedua terkait fokus evaluasi pelaksanaan program. Dari beberapa program yang diatur dalam UU No 27 Tahun 2012 tentang Ijin Lingkungan bahwa kebijakan pengelolaan lingkungan dalam rangka menjadikan pabrik semen ramah lingkungan yaitu pengelolaan lingkungan, penglelolaan limbah, pemantauan lingkungan dan monitoring. Berdasarkan hasil wawancara mendalam dari 3 (Tiga) Program tersebut PT semen Jawa telah melaksanakan ke 3 (Tiga) Program melalui:

1. teknologi ramah lingkungan diantarnya yaitu Elektrostatik Precifikator Dan Bag Filter untuk mengurangi polusi debu

2. Melakukan pengolahan air secara tertutup, hal ini bermaksud untuk mengurangi debit yang digunakan dalam proses produksi. Karena pabrik ini tidak menggunakan air tanah tetapi menampung air dengan membuat pound penampung air.

3. Mengimplementasikan program 3R (Reduce, Reuse, Recycle) untuk
DOI : doi.org/10.21009/jgg.081.03

mengurangi limbah yang ditimbulkan dalam proses produksi

4. Pabrik PT semenjawa telah memasang CEMS (Continuous Emission Monitoring System) teknologi ini membantu untung memonitoring tingkat emisi yang ditimbulkan oleh mesin produksi.

Selanjutnya evaluasi kebijakan grindle komponen yang ketiga yaitu menyangkut Alokasi sumberdaya dalam menunjang pelaksanaan programprogram kegiatan. Sampai akhirnya tercipta outcomes yang menjadi indikator kesuksesan suatu kebijakan dalam rangka mewujudkan pabrik semen ramah lingkungan dalam teori grindle disebutkan alokasi sumber daya ini menyangkut dua poin yaitu mengenai sarana prasarana dan pembiayaan,.

Berdasarkan hasil wawancara dengan pihak PT Semen Jawa sejauh ini perusahaan telah menyediakan sarana prasarana yang memadai untuk pengelolaan lingkungan melalui beberapa program yang disusun untuk mewujudkan pabrik semen ramah lingkungan, diantaranya Elektrostatik Precifikator Dan Bag Filter untuk mengurangi polusi debu, Melakukan pengolahan air secara tertutup, untuk pengelolaan limbah B3 sudah perusahaan sudah menyediakan TPS Limbah B3 untuk selanjutnya diangkut oleh transporter Limbah B3 
yang berijin, mengimplementasikan program 3R (Reduce, Reuse, Recycle).

Secara keseluruhan Sarana dan prasarana untuk melaksanakan pengelolaan lingkungan telah disediakan oleh Perusahaan sesuai kebutuhan dan telah digunakan dan dimanfaatkan dengan baik

\section{Selanjutnya komponen yang} keempat yaitu outcomes. Evaluasi outcomes difokuskan untuk mengindentifikasi manfaat yang diperoleh dari keberadaan PT Semen Jawa. Pada evaluasi outcomes PT Semen Jawa dibagi kedalam beberapa aspek bahasan yaitu a) penanganan keluhan masyarakat sekitar; b)dampak ekonomi; c) dampak sosial.

Berdasarkan hasil wawancara ,Perusahaan cukup kooperative pada Dinas Lingkungan Hidup dibuktikan dalam ketepatan pelaporan /6 bulan. Tetapi dalam penanganan keluhan masyarakat terdapat beberapa rekomendasi dari dinas yang belum dilaksanakan, Mengharapkan perusahaan lebih terbuka dalam memberikan informasi mengenai penanganan keluhan masyarakat, Perusahaan agar cepat tanggap dalam menangani dampak lingkungan yang dirasakan masyarakat akibat aktivitas pabrik.

Berdasarkan hasil interview dengan tokoh masyarakat sekitar menyebutkan, Masyarakat mengharapkan adanya perhatian lebih kepada masyarakat sekitar terutama dalam hal peningkatan ekonomi dan sosial, antara lain : perbaikan insfrastruktur jalan di area sekitar pabrik, perekrutan tenaga kerja mengutamakan masyarakat sekitar, peningkatan derajat kesehatan warga sekitar terutama warga terdampak langsung dan lain sebagainya

Pendekatan manajemen kolaboratif semakin sering digunakan untuk pengelolaan sumberdaya alam. Manajemen kolaboratif merupakan suatu pengaturan kemitraan dalam tanggungjawab dan kewenangan antara stakeholders dalam pengelolaan lingkungan yaitu pemerintah, pemerintah daerah dan komunitas lokal. Selain itu, berbagai LSM dan badan-badan sosial dan badan usaha/swasta yang memiliki kepedulian terhadap kelestarian lingkungan dapat berperan juga dalam pengelolaan. Bantuan yang sifatnya teknis dapat ditopang oleh pemerintah termasuk pendanaan. Dan mengenai keilmuan dapat ditunjang oleh akademis terkait dibidangnya.

Disamping itu, secara swadaya jika masyarakat lokal sudah memahami dan adanya rasa memiliki terhadap lingkungan masyarakatpun akan bersedia untuk turut serta dalam pendanaan atau pembiayaan program sesuai kemampuannya.

Manajemen kolaboratif menggunakan kemampuan dan minat 
masyarakat ditingkat lokal yang dikombinasikan dengan kemampuan pemerintah dalam menyediakan kebijakan serta perangkat hukum yang diperlukan atau bantuan lainnya. Hubungan ideal kemitraan tersebut tergantung pada kapasitas para pemangku kepentingan dan sifat alami sumberdaya situ/danau yang dikelola. Manajemen kolaboratif mencakup spectrum penataan pengelolaan yang luas dengan berbagai tanggungjawab dan kewenangan dari pemerintah dan masyarakat lokal. Manajemen kolaboratif yang sifatnya konsultatif yaitu pemerintah berkonsultasi dengan masyarakat tetapi keputusan ada ditangan pemerintah. Manajemen kolaboratif yang kooperataif yaitu pemerintah, pihak perusahaandan masyarakat lokal bekerjasama secara setara dalam pengambilan keputusan.

Manajemen kolaboratif yang didelegasikan yaitu masyarakat lokal mempunyai kewenangan pengelolaan dan memberitahukan keputusannya kepada pemerintah(Izzakatusholeha, 2015).

Menurut Sam'aun Jaja Raharja (2008) kolaborasi merupakan peristilahan kerjasama yang merujuk kepada sesuatu yang positif. Untuk memperkuat pernyataan ini, Munt mengemukakan pengertian kolaborasi sebagai kerja bersama (working together) untuk mencapai tujuan sebagaimana yang diinginkan individu, kelompok, lembaga,
DOI : doi.org/10.21009/jgg.081.03

atau organisasi untuk menghasilkan suatu keluaran yang bermakna dan berkelanjutan. Dalam kolaborasi terjadi suatu relasi antar organisasi dan dengan relasi tersebut akan tercipta kerjasama.

Kolaborasi mendorong hasil keputusan yang lebih baik yang mempemudah implementasi, menyiapkan lembaga dan masyarakat untuk menyongsong tantangan masa depan, membangun "jembatan” antara lembaga, organisasi dan individu (yang tidak hanya dibuat dan setelah itu selesai), tetapi jembatan yang menghasilkan kesepahaman, dukungan dan pengembangan kapasitas. Dengan adanya linkage interpersonal dan interorganizational, maka program akan lebih mudah diimplementasikan karena didukung oleh mereka yang terkena efek (Raharja, 2008).

Lebih lanjut menurut Sam'un Jaja Raharja (2008) bahwa langkah utama agar kerjasama tercapai secara efektif adalah dengan (a) proses pengambilan keputusan yang demokratis dalam posisi kesetaraan sebagai instrumen kerjasama dan menghilangkan ego sektoral yaitu (b) saling percaya (c) membangun visi dan misi bersama antara organisasi terkait yang diwujudkan dalam bentuk rumusan tujuan bersama dipadu dengan tujuan masing-masing tujuan indivdu organisasi (c) saling mendukung program antara satu instansi dengan instansi lain (voluntary). 
Hal ini bisa dicapai jika (a) para stakeholder aktif berpartisipasi dalam pengelolaan Situ yang diperlihatkan dalam kemampuan menyiapkan struktur dan kapasitas masing-masing organisasi (b) menjunjung tinggi dan menjaga komitmen atas kesepakatan yang telah dibuat bersama dengan tetap bekerjasama sampai dengan kerjasama itu sendiri bubar atau berhenti berdasarkan kesepakatan.

Situ/Rawa Gede perlu dikelola oleh lembaga kolaboratif dalam bentuk konsorsium pemerintah pusat, pemerintah daerah dan masyarakat lokal untuk pengelolaan dan pengembangan wisata air meliputi badan situ dan sempadannya serta daerah sekitarnya secara utuh.

\section{KESIMPULAN}

Walaupun Perusahaan sudah melaksanakan upaya pengelolaan lingkungan untuk mengurangi dampak lingkungan, tetapi secara garis besar hasil evaluasi pelaksanaan pengelolaan dalam rangka menciptakan pabrik semen ramah lingkungan belum berjalan efektif sehingga perlu beberapa upaya strategis yang dapat mendorong pelaksanaan kebijakan tersebut dapat berjalan efektif dan berdampak luas. Untuk itu di dalam pengelolaan lingkungan diperlukan pendekatan "Manajemen Kolaboratif" (collaborative management) dan partisipatif dari semua pemangku
DOI : doi.org/10.21009/jgg.081.03

kepentingan dalam rangka pengelolaan lingkungan dalam rangka mewujudkan pabrik semen ramah lingkungan melalui pengaturan kerjasama dalam tangungjawab dan kewenangan antara pemerintah pusat dalam hal ini KLHK , pemerintah daerah Kabupaten Sukabumi dalam hal ini Diwakilkan oleh Dinas Lingkungan Hidup, Pemrakarsa dalam hal ini perusahaan dan masyarakat lokal dalam semua aspek.

\section{DAFTAR PUSTAKA}

Djajadiningrat, Surna T, Melia Famiola, 2004. Kawasan Industri Berwawasan Lingkungan (Eco Industrial Park), Rekayasa Sains, Bandung.

Fandeli, Chafid, 2000. Analisis Mengenai Dampak Lingkungan Prinsip Dasar dan Pemapanannya Dalam Pembangunan, Liberty : Yogyakarta.

Fityatur Rohmah, Agus Luthfi, Aisah Jumiati, 2015. Dampak Sosial Ekonomi Pabrik Semen Puger di Kecamatan Puger Kabupaten Jember. Jurnal Ekonomi Pembangunan.

Grindle, S. Merilee, 1980. Politics and Policy Implementation in The Third World. New Jersey: Princeton Univercity Press.

Izzatusholekha, dkk. 2015. Kebijakan Pengelolaan Situ Terpadu sebagai 
wujud pembangunan berkelanjutan

di Tangerang Selatan. Konfrensi

Internasional Malaysia - Indonesia

Jogyakarta.

Sam'un Jaja Raharja. 2008. Manajemen

Kolaboratif dalam Pengelolaan

DAS Citarum. Disertasi. FISIP UI

Purnaweni, Hartuti, 2014 Kebijakan

Pengelolaan Lingkungan di Kawasan Kendeng Utara Provinsi Jawa Tengah. Jurnal Ilmu Lingkungan Volume 12 Issues 1: 53 -54 .

PPLH Undip dan Biro Bina Lingkungan Hidup Propinsi Jawa Tengah, 1990. Penyusunan Evaluasi PelaksanaanAMDAL di Jawa Tengah.

Undang Undang No 27 TAHUN 2012 tentang Ijin Lingkungan dan AMDAL

Undang Undang No: 32 Tahun 2009 tentang Perlindungan dan Pengelolaan Lingkungan Hidup. 